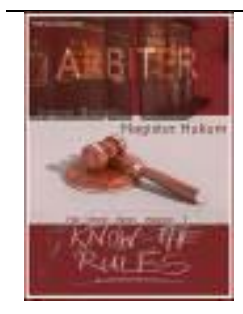

ARBITER: Jurnal Ilmiah Magister Hukum, 1(1) 2020: 117-127,

\author{
ARBITER: Jurnal Ilmiah Magister Hukum
}

Available online http://jurnalmahasiswa.uma.ac.id/index.php/arbiter

\title{
Perlindungan Hukum Terhadap Anak Korban Kekerasan: Studi Kasus Putusan Pengadilan Negeri Gunungsitoli
}

\section{Legal Protection of Children Victims of Violence: Case Study of Gunungsitoli District Court's Decision}

\author{
Hipotesa Hia1)*, Mahmud Mulyadi2) \& Taufik Siregar ${ }^{3)}$
}

1) Program Pasca Sarjana, Magister Ilmu Hukum, Universitas Medan Area, Indonesia

2) Fakultas Hukum, Universitas Sumatera Utara, Indonesia

3) Fakultas Hukum, Universitas Medan Area, Indonesia

\begin{abstract}
Abstrak
Adapun tujuan dan manfaat penelitian ini adalah untuk mengetahui kekerasan pada anak dipengadilan gunungsitoli, untuk mengetahui upaya hukum dalam perlindungan anak terhadap kekerasan anak, untuk mengetahui faktor penghambat dalam perlindungan anak dalam pengadilan negeri gunungsitoli. Manfaatnya adalah untuk memberikan masukan kepada pengadilan negeri gunungsitoli mengenai perlindungan hukum terhadap korban kekerasan. Penelitian ini bersifat deskriptif analitis, artinya menggambarkan fakta-fakta yang diteliti dan hubungan dengan peraturan perundang-undangan, teoriteori dan pendapat ahli hukum. Kesimpulan dan saran dalam perlindungan hukum menurut hukum positif Indonesia tidak perna menjamin terpenuhinya hak anak, hususnya hak anak yang mendapatkan pendidikan. Dengan ini kewajiban negara secara yuridis dalam perlindungan anak akan tergantung pada hukum positif yang ada di dalam negara tersebut, agar perlindungan anak bisa memadai dalam penerapan anak, dan usaha perlindungan anak perlu adanya dukung oleh pemerintah dan masyarakat dalam hal kenyamanan anak tersebut yang efektif dan komprehensif. Dalam hal ini mengingat kekerasan terhadap anak setiap tahunnya meningkat, maka perlu perlindungan hukum yang harus diperahtikan secara serius baik pemerintah, masyarakat dan lembaga-lembaga Swadaya Masyarakat lainnya.
\end{abstract}

Kata Kunci: Perilindungan Hukum, Anak korban kekerasan.

\section{Abstract}

The purpose and benefits of this research are to find out violence against children in Gunungsitoli court, to find out legal efforts in protecting children against child abuse, to find out the inhibiting factors in protecting children in Gunungsitoli District Court. The benefit is to provide input to the Gunungsitoli district court regarding legal protection for victims of violence. This research is analytical descriptive, which means describing the facts studied and the relationship with the legislation, theories, and opinions of legal experts. Conclusions and advice on legal protection according to positive law Indonesia never guarantees the fulfillment of children's rights, especially the rights of children who receive an education. Hereby the state's legal obligations in child protection will depend on the positive laws that exist in the country, so that child protection can be adequate in the application of children, and efforts to protect children need support from the government and the community in terms of effective and comprehensive child comfort. In this case, given the increase in violence against children every year, it is necessary to have the legal protection that must be taken seriously by the government, the community and other nongovernmental organizations.

Keywords: Legal Protection, Child victims of violence.

How to Cite: Hia, H., Mulyadi, M., \& Siregar, T. (2019). Perlindungan Hukum Terhadap Anak Korban Kekerasan: Studi Kasus Putusan Pengadilan Negeri Gunungsitoli. ARBITER: Jurnal Ilmiah Magister Hukum, 1(2), 117-127,

*E-mail: gantiaza@yahoo.co.id

ISSN 2722-1865 (Online) 


\section{PENDAHULUAN}

Di Indonesia salah satu masalah besar yang marak diperbincangkan adalah tindak kriminal terhadap anak. Mulai darikekerasan, pembunuhan, penganiayaan dan bentuk tindakan kriminal lainnya yang berpengaruh negatif bagi kejiwaan anak. Seharusnya seorang anak diberi pendidikan yang tinggi, serta didukung dengan kasih sayang keluarga agar jiwanya tidak terganggu. Hal ini terjadi karena banyak orangtua menganggap kekerasan pada anak adalah hal yang wajar. Mereka beranggapan kekerasan adalah bagian dari mendisiplinkan anak mereka lupa bahwa orang tua adalah orang yang paling bertanggung jawab dalam mengupayakan kesejahteraan, perlindungan, peningkatan kelangsungan hidup, dan mengoptimalkan tumbuh kembang anaknya. Keluarga adalah tempat pertama kali anak belajar mengenal aturan yang berlaku di lingkungan keluarga dan masyarakat. Kekerasan terhadap anak dapat diartikan sebagai perilaku yang sengaja maupun tidak sengaja yang ditujukan untuk mencederai atau merusak anak, baik berupa serangan fisik maupun mental (Indrasari, 2002). Melihat kondisi kekerasan pada anak yang sangat memprihatinkan, maka perlu adanya perlindungan hukum bagi anak dari kekerasan pada anak, karena anak juga merupakan cikal bakal lahirnya suatu generasi baru yang merupakan penerus bangsa ini.

Lebih tragis lagi jika dicermati bahwa dalam berbagai kasus-kasus kekerasan pada anak pelakunya adalah pihak-pihak yang seyogianya orang tua bahkan tetangga pun berperan dalam melakukan kekerasan pada anak. Bagaimanapun, tidak boleh dilupakan puluhan ribu anak lain yang telah merasakan kekerasan dan yang tidak mampu bertahan mengalami perlakuan buruk, dan jutaan anak lainnya yang sampai saat ini masih menderita dalam kekerasan yang dilakukan oleh pihak-pihak yang tidak bertanggung jawab. Satu-satunya lembaga bagi anak yang diperlakuan buruk ini adalah adanya lembaga perlindungan bagi anak-anak yaitu Komisi Perlindungan Anak Indonesia yang sangat berperan dalam memberikan perlindungan terhadap anak agar terbebas dari perlakuan buruk terhadap kekerasan pada anak. Pemenuhan hak-hak tersebut di lakukan dengan tujuan demi kepentingan terbaik bagi masa depan anak dan masa depan bangsa dan negara.

Menurut Hurlock (Azis, 1998) manusia berkembang melalui beberapa tahapan yang berlansung secara berurutan, terus menerus dan dalam tempo perkembangan yang tertentu dan bisa berlaku umum. Tahapan perkembangan tersebut dapat dilihat pada uraian berikut: 1) Masa pra-lahir: dimulai saat terjadinya konsepsi lahir; 2) Masa jabang bayi: satu hari-dua minggu; 3) Masa bayi: dua minggu-satu tahun; 4) Masa anak: masa anak-anak awal: 1 tahun- 6 tahun anak-anak lahir 6 tahun-12 tahun/13 tahun; 5) Masa remaja: 12/13 tahun-12 tahun; 6) Masa dewasa: 21 tahun-40 tahun; 7) Masa tengah bayi: 40 tahun-60 tahun; dan 8) Masa tua: 60 tahun-meninggal.

Pada hakikatnya anak dapat melindungi diri sendiri dari berbagai macam tindakan yang menimbulkan kerugian bagi anak, fisik, sosial dalam berbagai bidang dan penghidupan. Anak harus dibantu oleh orang lain dalam melindungi dirinya dalam kekerasan anak, mengingat situasi tersebut anak perlu adanya perlindungan bagi oleh orang tua dan pemerintah, perlindungan bagi anak tersebut harus dipertegas dengan penetapan undanng-undang yang bisa melindungi anak dari tindak pidana kekerasan anak.

Banyak orang tua menganggap kekerasan pada anak adalah hal yang wajar. Mereka beranggapan kekerasan adalah bagian dari mendisiplinkan anak mereka lupa bahwa orang tua adalah orang yang paling bertanggung jawab dalammengupayakan 
kesejahteraan, perlindungan, peningkatan kelangsungan hidup, dan mengoptimalkan tumbuh kembang anaknya. Kekerasan anak adalah perlakuan orang dewasa atau anak yang lebih tua dengan menggunakan kekuasaan atau otoritasnya terhadap anak yang tak berdaya yang seharusnya menjadi tanggung jawab atau pengasuhnya, yang berakibat penderitaan, kesengsaraan, cacat atau berdampak pada kematian (AA Lubis, Rizkan Zulyadi, dkk, 2019).

Dalam beberapa kasus anak-anak yang mengalami penganiayaan tidak menunjukkan gejala-gejala seperti diatas. Banyak faktor lain yang berpengaruh seperti seberapa kuat status mental anak, kemampuan anak mengatasi masalah dan penyesuaian diri. Ada kemungkinan anak tidak mau menceritakannya karena takut diancam, atau bahkan dia mencintai orang yang melakukan penganiyaan tersebut (Marlina, dan Elvi Z. 2008); Safrina, dkk., 2010; Sinaga, dkk., 2010; Simanjuntak, dkk., 2010; Nainggolandkk., 2010; Zai, dkk, 2011).

\section{METODE PENELITIAN}

Metode penelitian yang digunakan dalam penulisan hukum ini metode deskriptif analitis, artinya menggambarkan fakta-fakta yang diteliti dan hubungan dengan peraturan perundang-undangan, teori-teori dan pendapat ahli hukum. Penelitian ini menggunakan metode pendekatan normatif yaitu menguji dan mengkaji yang diperoleh dengan bertitik tolak pada aspek hukum (yuridis) melalui studi dokumen. Teknik pengumpulan data menggunakan penelitian kepustakaan (Library Research) untuk memperoleh data sekunder yang terdiri dari: a) Bahan hukum primer meliputi: peraturan perundang-undangan yang terkait; dan b) Bahan hukum sekunder meliputi: buku-buku literatur, karya-karya ilmiah, artikel-artikel dan dokumen-dokumen tertulis lainnya. Data-data penelitian yang diperoleh selanjutnya dianalisis secara kualitatif, yang menjabarkan dengan kata-kata sehingga merupakan kalimat-kalimat yang mudah dimengerti, sistematis dan dapat dipertanggung jawabkan.

\section{HASIL DAN PEMBAHASAN}

\section{Tinjauan Tentang Aturan Perlindungan Hukum Terhadap Anak Korban Kekerasan}

Pengertian anak terkait dengan batasan umur, ditemukan banyak literatur yang memberi batasan umur anak yang berbeda-beda. Dalam hal ini, dapat ditelusuri berdasarkan fase-fase perkembangan anak yang menunjukkan kemampuan atau kecakapan seorang anak untuk bertindak. Hal ini juga mengakibatkan adanya penafsiran yang mengartikan istilah-istilah anak dan belum dewasa secara campur aduk sehingga ukuran atau batas umurnya juga berbeda-beda (Ghazali, 1998).

\section{Prinsip-prinsip Perlindungan Anak}

1) Anak tidak dapat berjuang sendiri

Salah satu prinsip yang digunakan dalam perlindungan anak adalah anak itu modal utama kelangsungan hidup manusia, bangsa, dan keluarga, untuk itu hakhaknyaharus dilindungi. Anak tidak dapat melindungi sendiri hak-haknya, banyak pihak yang mempengaruhi kehidupannya. Negara dan masyarakat berkepentingan untuk mengusahakan perlindungan hak-hak anak (Soeaidy, 1990).

2) Kepentingan terbaik anak (the best interest of the child)

Agar perlindungan anak diselenggarakan dengan baik dianut prinsip yang menyatakan bahwa kepentingan terbaik anak harus dipandang sebagai of paramountimportence (memperoleh prioritas tertinggi) dalam setiap keputusan yang menyangkut anak. Tanpa prinsip ini perjuangan untuk melindungi anak akan 
mengalami banyak batu sandungan. Prinsip the best interest of the child digunakan karena dalam banyak hal anak "korban". Disebabkan ketidaktahuan (ignorance) karena usiaperkembangannya. Jika prinsip ini diabaikan, maka masyarakat menciptakan monster-monster yang lebih buruk dikemudian hari.

3) Ancangan daur kehidupan (life circle approach)

Perlindungan anak mengacu pada pemahaman bahwa perlindungan harus dimulai sejak dini dan terus menerus. Janin yang berada dalam kandungan perlu diindungi dengan gizi, termasuk yodium dan kalsium yang baik melalui ibunya. Jika ia telah lahir, maka diperlukan air susu ibu dan pelayanan kesehatan primer dengan memberikan pelayanan imunisasi dan lain-lain, sehingga anak terbebas dari berbagai kemungkinan cacat dan penyakit Masa-masa prasekolah dan sekolah, diperlukan keluarga, lembaga pendidikan, dan lembaga sosial atau keagamaan yang bermutu.

\section{Aturan Tindak Pidana Kekerasan Pada anak}

Menurut JCT. Simorangkir, hukum adalah peraturan yang bersifat memaksa yang menentukan tingkah laku manusia dalam lingkungan masyarakat yang dibuat oleh badan-badan resmi yang berwajib. Defenisi hukum ini penting untuk mengetahui sifat dan tujuan dibuatnya hukum itu sendiri. Tujuan hukum itu sendiri adalah untuk untuk memperoleh kebenaran dan keadilan. Menurut Van Apeldoorn tujuan hukum adalah untuk mengatur pergaulan hidup dengan manusia lain secara damai (Simorangkir, et al, 2008).

\section{Perlindungan Hukum Terhadap Anak Korban Kekersan (Putusan Pengadilan Negeri Gunung Sitoli )}

Anak adalah bagian yang tidak terpisahkan dari keberlangsungan hidup manusia dan keberlangsungan sebuah bangsa dan Negara agar kelak mampu bertanggung jawab dalam keberlangsungan bangsa dan Negara. Setiap anak perlu mendapat kesempatan yang seluas-luasnya untuk tumbuh dan berkembang secara optimal, baik fisik, mental, maupun sosial. Untuk itu, perlu dilakukan upaya perlindungan untuk mewujudkan kesejahteraan anak dengan memberikan jaminan terhadap pemenuhan hak-hak tanpa adanya perlakuan diskriminatif.

Negara menjunjung tinggi Hak Asasi Manusia (HAM), termasuk di dalamnya Hak Asasi Anak yang ditandai dengan adanya jaminan perlindungan dan pemenuhan hak anak dalam Undang Undang Dasar Negara Republik Indonesia Tahun 1945 dan beberapa ketentuan peraturan perundang-undangan lainnya baik yang bersifat nasional maupun yang bersifat internasional. Jaminan ini dikuatkan melalui ratifikasi konservasi internasional tentang Hak Anak, yaitu pengesahan Konvensi Hak Anak melalui Keputusan Presiden Nomor 36 tahun 1990 tentang Pengesahan Convention On The Rights Of The Child (Konvensi Tentang Hak-Hak Anak). Negara, pemerintah, pemerintah daerah, masyarakat, keluarga dan orang tua berkewajiban untuk memberikan perlindungan dan menjamin terpenuhinya Hak Asasi Anak sesuai dengan tugas dan tanggung jawabnya. (Rizkan Zulyadi, dkk, Dessy Agustina Harahap, dkk, Anggreini Atmei, dkk, Riswan Munthe, dkk 2019).

Perlindungan terhadap Anak untuk mendapatkan perlakuan dan kesempatan yang sesuai dengan kebutuhannya dalam berbagai bidang kehidupan, sehingga dalam melaksanakan upaya perlindungan terhadap Hak Anak oleh pemerintah harus didasarkan pada prinsip Hak Asasi Manusia yaitu penghormatan, pemenuhan dan perlindungan atas Hak Anak (M. Syahputra, Lubis, Sri Hidayani Muazzul, dkk 2019). Sebagai implementasi dari ratifikasi tersebut, Pemerintah telah mengesahkan Undang- 
Undang Nomor 23 Tahun 2002 tentang Perlindungan Anak, yang secara substantive telah mengatur beberapa hal antara lain persoalan Anak yang sedang berhadapan dengan hukum, Anak dari kelompok minoritas, Anak dari korban eksploitasi ekonomi dan seksual, anak yang diperdagangkan, Anak korban kerusuhan, Anak yang menjadi pengungsi dan anak dalam situasi konflik bersenjata. Perlindungan Anak yang dilakukan berdasarkan prinsip nondiskriminasi, kepentingan terbaik bagi Anak, hak untuk hidup, tumbuh dan berkembang.

\section{Perlindungan Korban Kejahatan Sebagai Wujud Perlindungan Hak Asasi}

Manusia Manusia adalah makhluk sosial (zoon politicon). Konsekuensi dari eksistensi manusia sebagai makhluk sosial adalah perlunya diciptakan suatu hubungan yang harmonis antara manusia yang satu dengan yang lainnya. Kondisi ini dapat diwujudkan melalui kehidupan saling menghormati dan menghargai bahwa diantara mereka terkandung adanya hak dan kewajiban (Muladi, 2005).

Dari berbagai hak yang melekat pada diri manusia, ada hak yang sangat fundamental dan mendasar yang diberikan kepada manusia sejak lahir sehingga keberadaannya merupakan suatu keharusan, tidak dapat diganggu gugat, bahkan harus dilindungi, dihormati dan dipertahankan yaitu hak asasi manusia. (Rizkan Zulyadi, Dessy Agustina Harahap, dkk 2019).

Hak asasi manusia adalah hak kodrati manusia, begitu manusia dilahirkan, langsung hak asasi itu melekat pada dirinya sebagai manusia sehingga tidak dapat dicabut oleh siapapun, sebab pencabutan hak asasi manusia berarti hilangnya sifat kemanusiaan yang ada pada diri manusia. Artinya harkat dan martabat manusia sebagai ciri khas kemanusiaan manusia tidak lagi dihormati dan diakui.

Dalam konteks hak asasi manusia, keberadaan manusia yang memiliki hak dan kewajibannya masing-masing, tidak dapat dipandang sebagai individu yang berdaulat yang dapat mempertahankan hak serta kewajibannya secara mutlak, melainkan haruslah dipandang sebagai personal sosial, yaitu suatu oknum pribadi sosial yang dibina oleh masyarakat, dan hidup terikat oleh masyarakat, serta mengendalikan hak asasi dan hak-hak lain dimana hak itu timbul karena hak hidupnya dalam masyarakat dan penggunaannya harus diselaraskan dengan kepentingan umum.

\section{Posisi Kasus Putusan Pengadilan Negeri Gunungsitoli}

1) Putusan No. 7/Pid.Sus/2016/PN Gst

a. Kronologi kasus

Bahwa ia Terdakwa ABDUL KADIR MENDROFA alias ama marlin pada hari minggu tanggal 08 Nofember 2015 sekitar pukul 02:30 wib, ketika anak korban (Umur 15 tahun sesuai dengan kutipan akta kelahiran No 1278-LT-16112011-0032 tanggal 24 nofember 2011) SEDANG mencari umpan pancing berupa humang (keong laut) terdakwa mendatangi anak korban dengan membawa sebilan parang ditangan kananya, dan setelah berhadapan dengan korban, terdakwa seakan-akan hendak mengayunkan parangnya (menggertak) kearah anak korban sehingga anak korban menahan terdakwa kedua tangannya, namun jari tangan telunjuk korban masuk ke dalam mulut terdakwa, langsung terdakwa menggigit jari tangannya tersebut dari gigitan terdakwa dengan mundur kebelakang, sehingga korban berusaha melepaskan jaringanya tersebut dengan mundur kebelakang, namun usaha korban tersebut terhalang kandang ayam yg ada di belakang anak korban, sehingga terdakwa menggunakan tangan kananya langsung mengayunkan sebilah parang miliknya kearah kening korban dan korban berusaha 
menahan oaring tersebut dengan menggunkan telapak tangannya kirinya. Sehingga perbuatan terdakwa, korban mengalami luka robek di pelipis kiri ukuran $6 \times 3 \times 1 \mathrm{~cm}$, tampak retak pada tulang tengkorak pelipis kiri ukuran $3 \times 0,7 \times 0,5 \mathrm{~cm}$, luka robek pada telapak tangan kiri ukuran $10,5 \times 3 \times 2 \mathrm{~cm}$ dan luka robek pada pangkal telunjuk tangan kanan $1 \times 0,2 \times 0,1 \mathrm{~cm}$. Dengan perbuatan terdakwa sebagaimana di atur dan di ancam pidana dalam pasal 80 ayat (2) Undang-undang RI No. 35 tahun 2014 tentang perubahan atas Undang-undang RI No. 23 Tahun 2002 Tentang perlindungan anak.

\section{2) Putusan No. 8/Pid.Sus-Anak/2016/PN Gst}

a. Kronolagi Kasus

Bahwa terdakwa pada hari sabtu tanggal 15 oktober 2016 sekitar pukul 16.00 wib, atau setidak-tidaknya pada suatu waktu tertentui dalam bulan oktober 2016, bertempat tinggal di desa S kec. Amandraya KABUPATEN NIAS SELATAN tepanya dilantai dua rumah milik sdr TG yang telah kosang tidak ada yang menempati tempat yang masih daerah hukum pengadilan negeri gunungsitoli" melakukan kekerasan atau ancaman kekerasan memaksa anak melakukan persetubuhan dengannya atau dengan orang lain" terhadap anak korban (berumur 8 tahun 10 bulan) perbuatan tersebut dilakukan dengan cara membunuh dan memperkosa.

3) Putusan No. 9/Pid.Sus/PN Gst

a. Kronologi Kasus

Bahwa terdakwa pada hari dan tanggal tidak bisa ditentukan lagi pada bulan agustus 2015 sekitar pukul 01.00 wib atau setidaknya pada suatu waktu masih dalam bulan agustus tahun 2015, bertempat di KABUPATEN NIAS SELATAN tepanya dikamar terdakwa serta di salah satu kebun masyarakat di DESA H KABUPATEB NIAS SELATAN atau setidak-tidaknya pada suatu tempat yang masih dalam daerah hukum pengadilan negeri gunungsitoli, melakukan kekerasan atau ancaman kekerasan memaksa anak yaitu korban umur 16 (Enam belas) Tahun melakukan persetubuhan dengannya satu dengan orang lain, jika antara beberapa perbuatan, meskipun masing-masing merupakan kejahatan, ada hubungannya sedemikian rupa sehingga harus dipandang sebagai perbuatan berlanjut.

\section{Faktor Penghambat Dalam Perlindungan Hukum Terhadap Anak Korban Kekerasan}

Faktor Aturan Hukum Dan Peraturan Perundang-Undangan. Penyidikan tindak pidana korban kekerasan yang dialami anak adalah merupakan langkah atau proses awal dari penegakan hukum dalam upaya memberantas tindakan kekerasan anak sebagaimana tujuan pembentukan undang-undang nomor 23 tahun 2002 sebagaimana telah diubah dalam undang-undang nomor 35 tahun 2014 tentang perlindungan anak. Dalam melaksanakan tugasnya terhadap penyidikan tindakan pidana kekerasan yang di alami anak dengan korban anak ternyata tidak jarang mengalami kendala (Waluyadi, 2009).

Tidak ada kendala pada faktor aturan hukum dalam perlindungan hukum bagi anak sebagai korban tindak pidana kekerasan anak, karena aturan hukum yang diberikan kepada anak selaku korban sudah diatur secara khusus di dalam Undangundang Nomor 35 Tahun 2014 perubahan atas Undang-undang Nomor 23 Tahun 2002 tentang Perlindungan Anak. Undang-undang Nomor 35 Tahun 2014 tentang Perlindungan Anak sudah memberikan aturan-aturan yang khusus untuk memberikan perlindungan kepada anak sebagain korban tindak pidana kekerasan anak. 
Pemberian perlindungan hukum kepada anak sebagai korban didasarkan pada undang-undang nomor 23 tahun 2002 sebagimana telah di ubah dalam undang-undang nomor 35 tahun 2014 tentang perlindungan anak salah satunya adalah menjatuhkan sanksi pidana kepada pelaku tindak pidana pelecehan tersebut. Undang-undang nomor 23 tahun 2002 sebagaimana telah diubah dalam undang-undang nomor 35 tahun 2014 tentang perlindungan anak mengatur tentang bentuk-bentuk perlindungan khusus yang dapat diberikan pada anak yang menjadi korban kejahatan, ekspoitasi baik secara ekonomi atau seksual, fisik dan psikis.

Selain konvensi hak anak diatas, secara umum undang-undnag dasar 194 telah mengatur secara jelas perlindungan hukum bagi anak di bawah umur, yang seharusnya negara memberikan kelangsungan hidup secara penuh atas diskriminasi bahkan kekerasan seksual terhadap anak. Hal tersebut dituangkan di dalam pasal 28B Ayat (2) undang-undang dasar 1945 yang berbunyi setiap anak berhak atas kelangsungan hidup, tumbuh kembang,serta berhak atas perlindungan dari kekerasan seksual dan diskriminasi.

Faktor Aparat Penegak Hukum. Faktor penegakan hukum masih menjadi kendala yaitu dapat dilihat dari cara aparat penegak hukum memberikan sanksi pidana kepada pelaku yang aturan baru seharusnya paling singkat 5 (lima) tahun terdapat di dalam Pasal 82 (UU Nomor 35 Tahun 2014 tentang Perlindungan Anak), namun seringkali aparat penegak hukum memberikan sanksi pidananya hanya 3 (tiga) tahun yang terdapat dalam Pasal 82 (UU Nomor 23 Tahun 2002 tentang Perlindungan Anak). Dengan hal tersebut penulis berkesimpulan aparat penegak hukum tidak paham terkait sudah diterapkannya peraturan yang baru yaitu Undang-Undang Nomor 35 Tahun 2014 perubahan atas Undang-undang Nomor 23 Tahun 2002 Tentang Perlindungan Anak. Jika aparat penegak hukum paham dengan adanya peraturan yang baru tidak mungkin mereka masih menggunakan aturan yang lama, padahal jelas di dalam Pasal 82 UndangUndang Nomor 35 Tahun 2014 tentang Perlindungan Anak (Didik, Mansur, \& Gultom, 2007).

Catur wangsa meliputi kepolisian (lembaga penyidik), jaksa (lembaga penuntut), hakim (lembaga peradilan) dan pengacara atau advokad. Untuk menegakkan hak- hak anak dan hukum anak, menghadapi permasalahan hukum yang melanda Indonesia yakni keterbatasan kemampuan penegak hukum yang memahami hukum anak dan hak- hak anak, kualitas pendidikan dan keahlian masing- masing aparat penegak hukum dan kemampuan organisasi dalam menegakkan hukum anak dan hak- hak anak.

Pihak kepolisian sendiri telah menerapkan beberapa pasal dakwaan terhadap bentuk-bentuk tindak pelecehan seksual anak dibawah umur, baik itu pemerkosaan maupun pencabulan. Pasal tersubut terdapat dalam Undang-Undang Nomor 23 Tahun 2002 sebagaimana telah diubah dalam undang-undang nomor 35 Tahun 2014 tentang Perlindungan Anak. Pasal yang didakwakan biasanya Pasal 76 E jo Pasal 82 (1) UndangUndang Nomor 35 Tahun 2014 tentang perubahan atas UndangUndang Nomor 23 Tahun 2002 tentang Perlindungan Anak, Pasal 76 D jo Pasal 81 (2) Undang-Undang Nomor 35 Tahun 2014 tentang perubahan atas UndangUndang Nomor 23 Tahun 2002 tentang Perlindungan Anak, Pasal 76 D jo Pasal 81 ayat (1) Unda-Undang Nomor 35 Tahun 2014 tentang perubahan atas UndangUndang Nomor 23 Tahun 2002 tentang Perlindungan Anak, dan Pasal 76 E jo Pasal 82 (1) Unda-Undang Nomor 35 Tahun 2014 tentang perubahan atas Undang-Undang Nomor 23 Tahun 2002 tentang Perlindungan Anak. 
Selain Kepolisian dan Advokat, dalam hal perlindungan anak pemerintah membentuk penegak hukum lainnya untuk membantu melakukan perlindungan hukum, yaitu Komisi Perlindungan Anak Indonesia sebagaimana yang telah diatur dalam Pasal 74 ayat (1) Undang-Undang No.35 tahun 2014 bahwa dalam rangka meningkatkan efektivitaspengawasan penyelenggaraan pemenuhan Hak Anak, dengan UndangUndang ini dibentuk Komisi Perlindungan Anak Indonesia yangbersifat independen. Pasal 76 juga mengatur bahwa Komisi Perlindungan Anak Indonesia dalam memberikan perlindungan terhadap anak korban tindak pidana kekerasan dalam rumah tangga dimulai dari proses penyidikan di kepolisian sampai setelah selesainya proses pengadilan.

Sistem penegakan hukum sangat dipengaruhi pula oleh para penegak hukumnya yang menurut undang-undang kita kenal sebagai aparat penegak hukum adalah Polisi, Jaksa, Hakim. Selain ketiga aparatur tersebut secara informal seorang Pengacara juga dapat dipandang sebagai aparat penegak hukum karena tugas-tugasnya mendampingi ataupun menjadi kuasa dari seseorang dalam rangka memperoleh pelayanan hukum.

Secara sosiologis setiap penegak hukum akan memiliki kedudukan dan peranan didalam masyarakat dan kedudukan sosial tersebut merupakan posisi tertentu didalam struktur kemasyarakatan yang ada. Dengan kedudukannya tersebut setiap aparat penegak hukum dituntut memiliki sikap dan perilaku yang tidak tercela. Jika mental para penegak hukum tidak baik dan tidak berorientasi pada kebenaran substansial serta tidak berpihak pada keadilan masyarakat, maka kepercayaan masyarakat terhadapnya akan hilang.

Salah satu faktor yang memegang peranan penting dalam penegakan hukum terhadap perlindungan anak adalah faktor penegak hukumnya sendiri. Secara ideal bangsa Indonesia telah memiliki beberapa ketentuan pokok terkait peranan penegak hukum dalam menjaga stabilitas dan keamanan masyarakat seperti Undang-Undang Kepolisian Negara, Undang-Undang Pokok Kejaksaan dan juga tentang kekuasaan Kehakiman. Sayangnya sebagian besar kasus yang diangkat terkait kekerasan terhadap anak hanyalah kasus-kasus yang sebelumnya telah diekspos besar-besaran oleh media cetak dan elektronik, dimana pengaruh "interest groups" dan juga "public opinion" sangat kuat disini. Realitas yang ada di negeri kita ini sebenarnya masih ribuan bahkan jutaan kasus menyangkut kekerasan dan diskriminasi terhadap anak yang sama sekali tak tersentuh oleh hukum. Untuk itu sangat diperlukan adanya peran aktif tidak hanya dari masyarakat tapi juga yang utama adalah perhatian ekstra dari para aparat penegak hukumnya, sehingga akan tercipta kondisi aman khususnya bagi anak-anak penerus bangsa ini.

Faktor Budaya. Kebudayaan selalu beragam dan berganti-ganti. Banyaknya budaya yang cenderung "negatif" mengakibatkan adanya tindak pidana kejahatan, kebudayaan yang sering dilakukan masyarakat yang tidak sesuai dengan aturan hukum dapat menimbulkan masalah baru. Pada dasarnya kebudayaan memiliki fungsi yang sangat berpengaruh dalam kehidupan sehari-hari manusia, karena budaya merupakan salah satu dari kebiasaan yang selalu dikembangkan masyarakat. Penulis berkesimpulan bahwa masyarakat tidak memperhatikan tindak pidana pencabulan yang dilakukan oleh sesama jenis. Karena masyarakat menganggap setiap orang dikatakan melakukan pencabulan jika perbuatan tersebut dilakukan antara laki-laki dan perempuan (Soekanto, 1986).

Budaya hukum pada dasarnya mencakup nilai-nilai yang mendasari hukum yang berlaku, dan nilai-nilai mana merupakan konsepsi-konsepsi abstrak tentang apa yang 
dianggap baik sehingga patut untuk dipatuhi dan apa yang dianggap buruk sehingga harus dihindari. Dalam penegakan hukum nilai-nilai kultur tersebut diatas dapat dijabarkan dalam kaidah-kaidah dan pandangan yang mantap dalam sikap dan tindakan sebagai rangkaian nilai akhir untuk menciptakan suatu pembaharuan sosial (Law as a tool of social engineering), memelihara dan mempertahankan kontrol sosial guna tercipta kedamaian dalam pergaulan hidup masyarakat. (Zaini Munawir, dkk, M.Y.A Syaputra, dkk Maswandi, dkk \& Ari Kartika, dkk, 2019).

Dengan ini budaya hukum Indonesia ini masih menganggap bahwa anak merupakan otoritas dan tanggung jawab penuh orang tua. Ia bisa bisa melakukan apapun, bahkan kekerasan terhadap anak dengan alasan merupakan hak orang tua sepenuhnya, orang tua berfikir bahwa anak adalah seperti barang pribadi yang dimiliki sehingga bisa diperlakukan apa saja sekehendak hatinya. Belum lagi faktor mewarisi pola asuh orang tua sebelumnya, yang tanpa disadari telah melakukan tindak kekerasan pada anak atau itu cara ia mendidik anaknya, dan orang lain tdk boleh ikut campur. Sehingga pihak lain tidak bisa berbuat banyak apalagi melakukan intervensi, terlebih ketika orang tua dalam keadaan lelah, mendapat tekanan, atau menghadapi masalah maka anak rentan menghadapi sasaran pelampisan kemarahan orang tuanya.

\section{SIMPULAN}

Dalam perlindungan hukum menurut hukum positif Indonesia tidak perna menjamin terpenuhinya hak anak, hususnya hak anak yang mendapatkan pendidikan. Dengan ini kewajiban negara secara yuridis dalam perlindungan anak akan tergantung pada hukum positif yang ada di dalam Negara tersebut, agar perlindungan anak bisa memadai dalam penerapan anak, dan usaha perlindungan anak perlu adanya dukung oleh pemerintah dan masyarakat dalam hal kenyamanan anak tersebut yang efektif dan komprehensif.

Perlindungan Hukum mesti perlu menerapkan perlindungan anak bagi korban kekerasan yang dikaitkan dengan aturan tegas dalam hak-hak anak. Dalam hal ini harus diatur pertanggungjawabkan dan pemahaman masyarakat dan keluarga agar perlindungan anak perlu di tegaskan agar anak terhindar dari kekerasan bahkan pembunuhan yang menghilangkan nyawa anak. Pertimbangan dan perkembangan menunjukkan bahwa tindakan kekerasan sering terjadi berupa bentuk kekerasan fisik, psikik, bahkan seksual maupun penelantaran terhadap anak.

Pemerintah dan lembaga negara lainya berkewajiban dan bertanggungjawab terhadap anak untuk memberikan perlindungan hukum khusus kepada anak yang terkena kekerasan baik situasi darurat pun atau kekerasan yang mengakibatkan anak jadi korban kekerasan. Dapat diketahui bahwa hukum yang berlaku pada dasarnya merupakan wujud atau cermin masyarakat, hukum itu sendiri adalah sebuah produk kultural, sehingga tidak berlebihan bila hukum yang belaku merepresentasikan budaya dan nilai yang eksis di masyarakat agar perlindungan hukum bagi anak terarah sesuai kehendak masyarakat.

\section{DAFTAR PUSTAKA}

Abidin. S (2019). Model Komunikasi Interpersonal Orangtua terhadap Purba, D \& Zahara, E (2017). Hak Terhadap Anak Setelah Perceraian Yang Diakibatkan Oleh Pertengkaran Suami Istri Jurnal Ilmiah Penegakan Hukum 4 (1) 2017: 16-22

Akhbar, A.T.F, Maswandi \& Kartika A. (2019). Perlindungan Hukum Bagi Anak Dalam Tindak Pidana Pencurian Dengan Kekerasan Yang Mengakibatkan Matinya Korban (Studi Putusan No. 37/Pid.SusAnak/2017/PN. Mdn). JUNCTO, 1(2) 2019: 183-192, 
Azis, A. (1998). Aspek Hukum Perlindungan Anak. Jakarta: Grafika.

Didik, M., Mansur, A., \& Gultom, E. (2007). Urgensi Perlindungan Korban Kejahatan. Jakarta: Raja Grafindo. Ghazali, I. (1998). Hikma Penciptaan Makhluk. Jakarta: Lenteras.

Ginting, S.Y, Lubis, A.A, \& Zulyadi, R. (2019). Penerapan Sanksi Hukum Tindak Pidana Pemerkosaan Yang Dilakukan Oleh Anak (Studi Putusan No. 65/Pid.Sus-Anak/2017/PN. Mdn). JUNCTO, 1(2) 2019: 166-173,

Indrasari, W. (2002). Peranan Komisi Perlindungan Anak Indonesia Menurut Undang-Undang No.23 Tahun 2002 tentang Perlindungan Anak", makalah tidak dipublikasikan.

Lubis, M. Syahputra, Hidayani, Sri \& Muazzul. (2019). Kajian Hukum Terhadap Anak Berhadapan Hukum Dalam Tindak Pidana Pencurian Menurut Undang-Undang No. 11 Tahun 2012 Tentang Pengadilan Anak (Studi Putusan No. 67/Pid.Sus-Anak/2017/PN.Mdn). JUNCTO, 1(1) 2019: 100-112,

Marlina, dan Elvi Z., (2008), Perlindungan Hukum Terhadap Anak Yang Melakukan Perkawinan Anak di Bawah Umur, Mercatoria, 1 (2): 163-175.

Muladi. (2005). Hak Asasi Manusia Hakekat, Konsep dan Implikasinya Dalam Perspektif Hukum Dan Masyarakat. Bandung: Refika Aditama.

Nainggolan, M., Elvi Z., dan Saparuddin, (2010), Peranan Hakim dalam Memberikan Perlindungan Hukum terhadap Anak Korban Penyalahgunaan Narkotika (Studi Pengadilan Negeri Lubuk Pakam), Mercatoria, 3 (2): 116-132.

Nasution, A. (2019). Akibat Hukum Pengangkatan Anak Menurut Undang-Undang Nomor 23 Tahun 2002 tentang Perlindungan Anak, Jurnal Ilmiah Penegakan Hukum, 6 (1): $14-26$

Ritonga, M. S., Mulyadi, M. \& Mustamam (2019). Penerapan Restorative Justice Sebagai Model Perlindungan terhadap Anak (Studi Penanganan Perkara Anak Berhadapan dengan Hukum pada Wilayah Hukum Pengadilan Negeri Dumai Kelas IA). Journal of Education, Humaniora and Social Sciences (JEHSS). 2 (2): 318-334.

Safrina, R., Iman J., dan Arif, (2010), Perlindungan Hukum terhadap Anak Korban Kekerasan dalam Rumah Tangga, Mercatoria, 3 (1): $34-44$.

Saragih, Denny Hardi Pranata, Zulyadi, Rizkan \& Harahap, Dessy Agustina. (2019). Akibat Hukum Terhadap Anak Sebagai Pelaku Tindak Pidana Pencurian Yang Menyebabkan Kematian (Studi Putusan Nomor : 45/Pid.Sus-Anak.2018/PN. Lbp). JUNCTO, 1(1) 2019: 78-88,

Saragih, E.E., Mustamam \& Mukidi (2019). Kedudukan Anak Perempuan dalam Pembagian Harta Warisan menurut Hukum Islam (Studi Kasus Putusan Pengadilan Agama Medan No. 40/Pdt.G/2017/PA.Mdn). Journal of Education, Humaniora and Social Sciences (JEHSS). 2 (2): 307317.

Sidabutar, R. \& Suhatrizal. (2018). Perlindungan Hukum terhadap Anak yang Melakukan Tindak Pidana Pencabulan pada Putusan No.2/pid.sus/2014PN.Mdn. Jurnal Ilmiah Penegakan Hukum, 5 (1): 2231.

Silalahi, S.D, Munawir, Z \& Syaputra, M.Y.A, (2019). Perlindungan Hukum Bagi Pekerja Kontrak Yang Mengalami Pemutusan Hubungan Kerja Pada Masa Kontrak (Studi Kasus Putusan Nomor : 82/Pdt.Sus-Phi/2016/PN. Mdn). JUNCTO, 1(2) 2019: 174-182,

Simanjuntak, M., Januari S., dan Isnaini, (2010), Peran Polri dalam Penyidikan Tindak Pidana Kekerasan Seksual dalam Rumah Tangga (Studi di Unit Perlindungan Perempuan dan Anak Sat Reskrim Polresta Tebing Tinggi), Mercatoria, 3 (2):102-116.

Simorangkir, J. C. T., et al. (2008). Kamus Hukum. Jakarta: Sinar Grafika.

Sinaga, S.M., dan Elvi Z.L., (2010), Perlindungan Hukum terhadap Anak Yang Melakukan Kejahatan dalam Persidangan Anak, Mercatoria, 3 (1): 52 - 57.

Soeaidy, S. (1990). Dasar Hukum Perlindungan Anak. Jakarta: CV. Novindo Pustaka Mandiri.

Soekanto, S. (1986). Pengantar Penelitian Hukum. Jakarta: UI Press.

Surbakti, F.M. \& Zulyadi, R. (2019). Penerapan Hukum terhadap Anak sebagai Pelaku Tindak Pidana Pencurian dengan Kekerasan. Journal of Education, Humaniora, and Social Sciences (JEHSS), 2 (1): 143-166.

Suryani Fithri, B. (2018). Pendekatan Integral Penal Policy dan Non Penal Policy dalam Penanggulangan $\begin{array}{lllll}\text { Kejahatan Anak. DOKTRINA: JOURNAL OF LAW, } & \text { 69-89. }\end{array}$ doi:https://doi.org/10.31289/doktrina.v1i2.1922

Tekualu, Lisana Dewi Sidqin, Lubis , Anggreini Atmei \& Munthe , Riswan. (2019). Perlindungan Hukum Terhadap Korban Perdagangan Perempuan Dan Anak (Trafficking) (Studi Pengadilan Negeri Medan). JUNCTO, 1(1) 2019: 89-99,

Waluyadi. (2009). Hukum Perlindungan Anak. Bandung: Mandar Maju. 
Zai, A., Taufik S., dan Dedy I., (2011), Perlindungan Hukum Terhadap Anak yang Berhadapan dengan Hukum dalam Sistem Peradilan Anak, (Studi pada Wilayah Hukum Polres Nias), Mercatoria, 4 (2): 86-103. 